\title{
Empirical Study of the Interconnection between Value Orientations and Ethnic Identity of Student Youth
}

\section{Емпіричне дослідження взаємозв'язку ціннісних орієнтацій та етнічної ідентичності студентської молоді}

Oksana Rybak

Assistant Lecturer of the Department of Psychology

E-mail: rybako@hotmail.com orcid.org/0000-0002-0596-7283

Researcher ID: D-8030-2019
Ivan Franko National University of Lviv

1, Universytetska street, Lviv, Ukraine, 79000
Львівський національний університет ілені Івана Франка вул. Університетська, 1, м. Львів, Україна, 79000

Original manuscript received February 15, 2019

Revised manuscript accepted March 14, 2019

\section{ABSTRACT}

In this article the peculiarities of the interconnection between value orientations and the formation of the ethnic identity of student youth are analyzed. To determine students' value orientations, a complex of techniques of domestic and foreign authors was used, they are: the test of cultural and value orientations by L. Pochebut, morphological test of vital values by V. Sopov and L. Karpushina, a test of sense-oriented orientations by J. Krambo and L. Maholik (adaptation of D. Leontiev). In order to determine the ethnic identity of 
student youth, a scale of the assessment of feelings related to ethnicity by $N$. Lebedeva, scale for evaluation the expressiveness of ethnic identity by N. Lebedeva, The Multigroup Ethnic Identity Measure by J. Phinny were also used. The study, which lasted from 2015 to 2018, comprised 476 students. Value orientations of students and the level of their ethnic identity are analyzed. Statistically significant differences of student's different levels of ethnic identity formation are described on the basis of such indicators of scales as traditional culture and modern culture. It is proved that students are more focused on the present, on modern events. Their values are focused on people, their rights, development of abilities, self-realization and self-actualization. It has been shown that student youth tends to recognize the right of society to regulate human behavior on the basis of morality, ethical norms and rules, and also to make individual decisions in the process of reconciling mutual needs, interests and plans for the future with a group, family, and work colleges. In addition, the studied group of students tends to be interested in environmental issues, harmony with nature, and its conservation. It has been found that students who gave more or less importance to different spheres of life had different level of ethnic identity. The existence of the relationship of value orientations and the level of ethnic identity is proved. It is concluded that students with certain value orientations differ in the level of ethnic identity.

Key words: values, value orientations, goals, ethnic identity, levels of ethnic identity, traditional culture, modern culture.

\section{Вступ}

Цінності залишаються незмінними упродовж тисячоліть. Водночас у кожного народу спостерігається властива тільки йому пріоритетність цінностей. Тобто, спостерігається виражений етнічний і географічний аспект цінностей. Більше того, групи всередині кожного етносу мають різні пріоритети цінностей залежно від соціодемографічних особливостей. Молоді люди, незважаючи на те, до якого народу належать чи у якій країні живуть, прагнуть пригод i новизни, тоді як для людей похилого віку важливими цінностями є безпека та збереження традицій. Урешті-решт, одні й ті ж слова, поняття цінностей мають різний зміст і відповідають різним груповим уявленням, часто протилежним. Наприклад, до таких цінностей належать тради- 
ції. Вони в усіх етносів різні. Ця цінність, тісно пов'язана з антропологічним типом етносу, має виражений етнічний аспект і зв'язок з етапом соціальної еволюції. Однак культурно-ціннісна орієнтація на традиції є у всіх народів. Пояснюємо це тим, що традиції зумовлені досвідом виживання й адаптації до нових умов (Почебут, 2010).

Усі етнокультури характеризуються органічною цілісністю. В основі будь-якої етнокультури лежать культурні універсалії, що творять цілісний образ світу людини. Цей образ людського світу включає аксіологічні компоненти. Вивчаючи ці компоненти, ми досліджуємо нормативноціннісну сторону етнічної традиції. Культурна цінність етнічної ідентичності має велике значення для самореалізації людини, що є результатом виховання людини в конкретній етнічній групі. Прийняття особистістю осмислених потреб постає необхідною умовою виникнення особистісних цінностей (Берберян, 2014).

Ціннісні орієнтації виступають вагомою психологічною складовою у структурі етнічної ідентичності, механізмом особистісного росту та самоактуалізації, а також являються динамічною системою. При освоєнні особистістю етнічної ідентичності відбувається процес рефлексивної діяльності, коли відновлюються контексти та смислові зв'язки. Таке освоєння є і розумінням етнокультурної традиції, в рамках якої знаходиться суб'єкт, і саморозумінням цього суб'єкта. Саморозуміння, в свою чергу, передбачає осмислення системи цінностей, життєвих цілей, мотивів поведінки суб'єкта, способів дій стосовно інших.

У процесі еволюції людство поступово сформувало усвідомлення народами спільності походження, поняття про батьківщину, предків, культурні відмінності, релігійні погляди. Етнічна ідентичність дає змогу людині усвідомити свою тотожність із групою, свою унікальність, відмінні ознаки від групи не лише своєї, але й чужої. Завдяки спілкуванню з представниками чужої групи відбувається оцінка значення етнічної приналежності, їі ролі в житті 
та діяльності людини. Розвиток етнічної самосвідомості й визначення етнічного статусу також не відбувається без участі етнічної ідентичності. Отже, етнічна ідентичність займає важливе місце у процесі становлення особистості й виконує необхідні функції: вона виступає орієнтиром у навколишньому світі, задає загальні життєві цілі.

Загалом, проблема ідентичності має солідну традицію вивчення у психології. Її родоначальником можна вважати В. Джемса з його концепцією усвідомлення особистістю своєї тотожності, своїх границь і місця у світі. На думку В. Джемса, уявлення про себе у людини складається у двох площинах: особистісній і соціальній. Звідси виникають і два аспекти ідентичності: в особистісному аспекті створюється образ самототожності, а в соціальному аспекті образ «Я» формується як сукупність соціальних зв'язків індивіда (Джемс, 1991).

На сьогоднішній день проведено чимало досліджень, присвячених різним аспектам проблеми ідентичності. Зокрема, роботи Т. Г. Стефаненко щодо етнічного самовизначення (Стефаненко, 2004); В. А. Ядова щодо вивчення соціально-психологічних механізмів формування ідентичності (Ядов, 2014); Н. Л. Іванової щодо соціальної ідентичності в різних соціокультурних умовах (Іванова, 2004). Проаналізувавши вищезгадані роботи, можна зробити висновки про те, що людина завжди прагне зберегти позитивну ідентичність.

Дж. Mapcia (Marcia, Waterman, Matteson, Archer \& Orlofsky, 1993) пропонує модель статусу ідентичності. Він визначає ідентичність як особливу структуру Его, внутрішню, самотворчу, динамічну структуру здібностей, вірувань та індивідуальних контекстів. На нашу думку, ідея Дж. Марсіа, що ця структура розкривається через паттерни розв'язання проблем, є надзвичайно важливою. Згідно цього підходу, вирішення будь-якої проблеми, навіть найменшої, допомагає людям зрозуміти власні особливості та значення свого життя в контексті формування ідентичнос- 
ті. Коли розглядаємо цей підхід до розвитку ідентичності, можемо стверджувати, що у процесі становлення особистості вирішується низка проблем ціннісно-орієнтаційного характеру, таких як соціалізація, приватність і самовизначення. Визначення та ціннісно-вольові аспекти є основною ідеєю роботи А. Вотермана (Waterman, 1999), де він визначає кореляцію між ідентичністю та системою цілей, цінностей і вірувань, що діють як «елементи ідентичності»: ідентичність, мораторій, первинна ідентичність, дифузна ідентичність. Модель етнічної ідентичності, сформована Дж. Mарсіа та його колегами (Marcia, 1993), цікава тим, що бере до уваги два критерії: 1) наявність або відсутність кризи; 2) наявність або відсутність важливих цілей, цінностей і вірувань. Ці етапи важливі у житті особистості, оскільки визначають напрямок їі діяльності. Наявність або ж відсутність кризи стає новою точкою відліку та діяльності особистості, певним «перезавантаженням». У свою чергу, наявність або ж відсутність важливих цілей і цінностей основоположно впливає на вектор руху людини або ж констатує його відсутність i, як наслідок, його пошук.

Наявність етнічної ідентичності надзвичайно важлива для адаптації до змін у культурі та збереження психічного здоров’ я. Канадський дослідник Д. Тейлор зазначає, що психічно здорова людина має чітко визначену колективну (етнічну, культурну) ідентичність. Така людина готова до осмисленої, позитивної взаємодії з фізичним, соціальним середовищем і світом, який змінюється (Taylor, 2002). У маргінальної щодо етнічної ідентичності особистості розвивається комплекс негативних індивідуально-психологічних властивостей, що свідчать про фрустрацію: відчуття психологічної незахищеності, замкненість, пасивність, небажання відстоювати цінності свої, свого роду й етнічної спільності.

О. М. Татарко та М. А. Козлова для характеристики, що описує результат адаптаційних процесів особистості й оцінює її готовність до зміни своєї життєвої ситуації, про- 
понують використовувати поняття «психологічне благополуччя». Суб'єктивна оцінка психологічного благополуччя відображає сприйняття індивідами їх положення у житті й системі цінностей відносно власних цілей, очікувань і стандартів. У кожній культурі існують домінуючі цінності-цілі. Ступінь відповідності між індивідуальними цілями та цілями, які схвалюються в культурі, згідно моделі C. Оайші (Diener, 2000), веде до формування позитивних почуттів індивіда (Татарко, 2006: 67).

Мета статті - дослідити взаємозв' язок ціннісних орієнтацій та етнічної ідентичності студентської молоді.

\section{Завдання статті}

Дослідження ціннісних орієнтацій студентства і сформованості їх етнічної ідентичності; виявлення взаємозв'язку між ціннісними орієнтаціями та компонентами етнічної ідентичності.

Емпіричне дослідження проводилось упродовж 20152018 років. Досліджуваними були студенти Львівського національного університету імені Івана Франка, Київського національного університету імені Тараса Шевченка, Запорізького національного університету, Чорноморського національного університету імені Петра Могили. Загалом досліджувану групу склали 476 студентів (із них 279 жінок і 197 чоловіків) віком від 17 до 26 років.

\section{Методи та методики дослідження}

Із метою емпіричного вивчення психологічних чинників культурно-ціннісних орієнтацій та етнічної ідентичності використано стандартизовані психодіагностичні методики: тест культурно-ціннісних орієнтацій Л. Г. Почебут, шкалу експрес-оцінки почуттів, пов'язаних з етнічною приналежністю, Н. М. Лебедєвої, шкалу експрес-оцінки вираженості етнічної ідентичності Н. М. Лебедєвої, морфологічний тест життєвих цінностей В. Ф. Сопова і Л. В. Карпушиної, тест сенсожиттєвих орієнтацій Дж. Крамбо і 
Л. Махолика (адаптація Д. О. Леонтьєва), методику вираженості етнічної ідентичності Дж. Фінні.

\section{Результати та дискусії}

Розподіл досліджуваних на групи з різним рівнем ідентичності проводився за допомогою кластерного аналізу емпіричних даних у загальній групі досліджуваних із використанням методу дерева кластеризації та методу k-середніх.

При кластеризації брались до уваги показники шкал «Когнітивний компонент етнічної ідентичності» й «Емоційний компонент етнічної ідентичності" методики Дж. Фінні. До показників обраних шкал застосовано процедуру стандартизації даних. За результатами кластерного аналізу виокремлено три кластери (рис. 1).

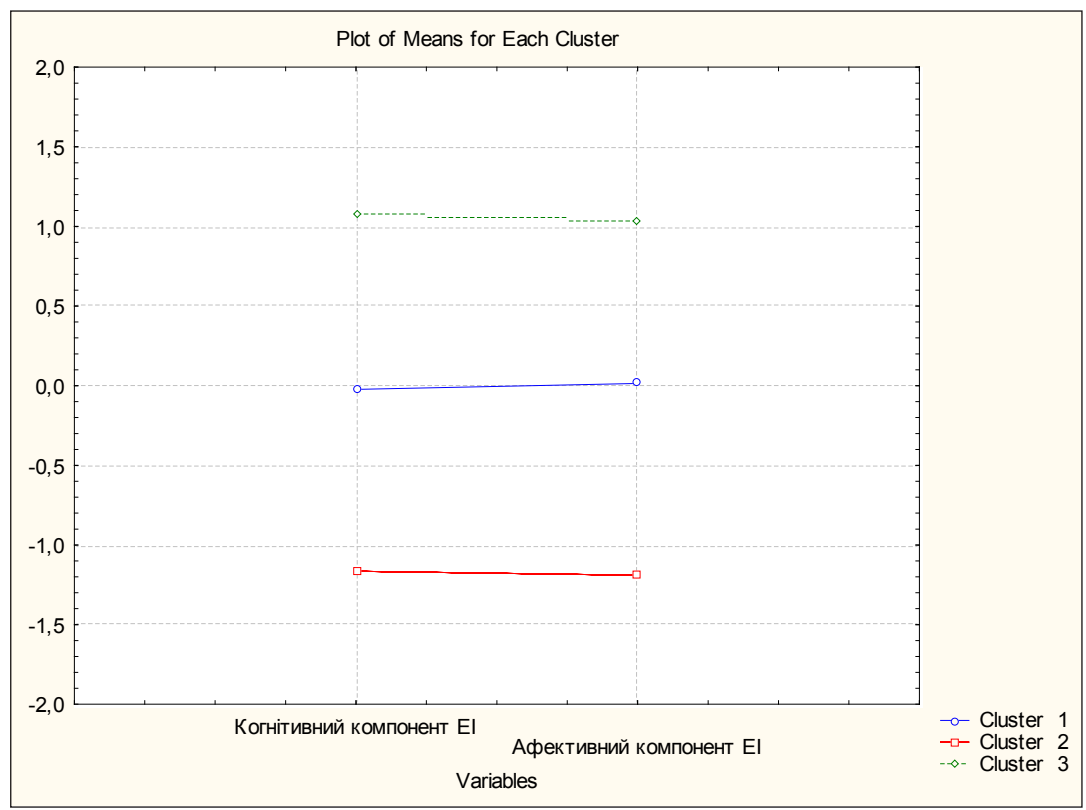

Puc. 1. Графік середніх значень показників когнітивного й афективного компонентів етнічної ідентичності за кластерами 
Із метою виявлення та психологічного аналізу відмінностей культурно-ціннісних орієнтацій студентів із різним рівнем сформованості етнічної ідентичності було застосовано однофакторний дисперсійний аналіз ANOVA i тест Шеффре.

Виявлено статистично значущі відмінності у студентів із різним рівнем сформованості етнічної ідентичності за такими показниками шкал методики «Культурно-ціннісні орієнтації» Л. Почебут, як традиційна культура та сучасна культура (рис. 2).

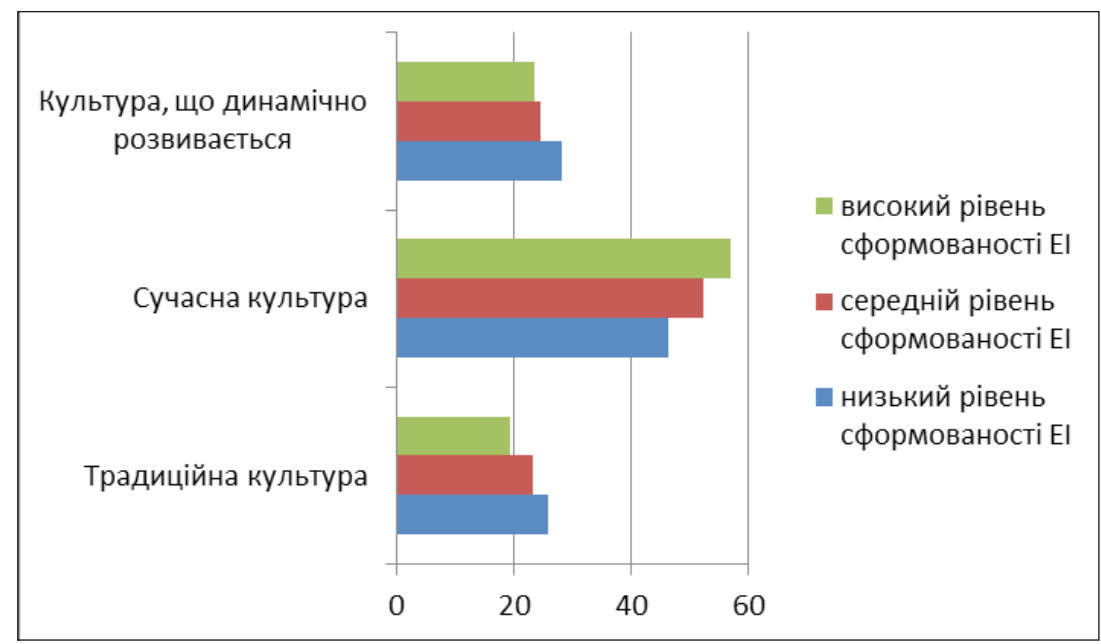

Puc. 2. Порівняння культурно-ціннісних орієнтацій (за Л. Почебут) студентів із різним рівнем сформованості етнічної ідентичності

Усі досліджувані більш орієнтовані на теперішнє, на сучасні події. Їхні цінності зосереджені на людині, її правах, покликанні, розвитку їі здібностей, самореалізації та самоактуалізації. Тобто, вони схильні визнавати право суспільства регулювати поведінку людини, спираючись на мораль, етичні норми і правила, а також приймати індивідуальні рішення у процесі погодження взаємних потреб, 
інтересів і планів на майбутнє з групою, сім’єю, робочим колективом. Крім того, деякі досліджувані схильні цікавитись екологічними питаннями, гармонією з природою, їі збереженням.

Однак студенти з високим рівнем сформованості етнічної ідентичності, порівняно зі студентами з низьким рівнем сформованості етнічної ідентичності, мають статистично нижчий рівень показника традиційна культура $\left(\mathrm{M}_{\mathrm{в}}=19,3, \mathrm{M}_{\mathrm{H}}=25,9\right)$ і статистично вищий рівень показника сучасна культура $\left(\mathrm{M}_{\mathrm{B}}=57,0, \mathrm{M}_{\mathrm{H}}=46,2\right)$.

Отож, досліджувані студенти з високим рівнем сформованості етнічної ідентичності більш орієнтовані на сучасні, теперішні події, а не на минуле, а також схильні більше цінувати внутрішню свободу, тому і не визнають залежності від найближчого соціального оточення. Вони схильні до прийняття самостійних індивідуальних рішень, а не колективних і під впливом старших за віком і статусом.

Порівняння виокремлених кластерів за шкалами методики «Сенсожиттєві орієнтації» Д. Леонтьєва дало змогу виявити значущі відмінності за всіма показниками шкал, а саме иілі в житті, процес життя, результат життя, локус контролю-Я, локус контролю-життя. Отримані результати за шкалами методики зображені на рис. 3.

Досліджувані студенти з високим рівнем сформованості етнічної ідентичності, порівняно зі студентами з низьким рівнем сформованості етнічної ідентичності, мають статистично вищий рівень показників процес життя $\left(\mathrm{M}_{\mathrm{в}}=32,3\right.$, $\left.\mathrm{M}_{\mathrm{н}}=29,4\right)$, результат життя $\left(\mathrm{M}_{\mathrm{B}}=32,5, \mathrm{M}_{\mathrm{н}}=29,7\right)$, локус контролю - $Я\left(\mathrm{M}_{\mathrm{B}}=27,3, \mathrm{M}_{\mathrm{H}}=25,4\right)$, локус контролюжиття $\left(\mathrm{M}_{\text {в }}=32,9, \mathrm{M}_{\mathrm{H}}=30,7\right)$. Порівняно зі студентами із середнім рівнем сформованості етнічної ідентичності, досліджувані студенти з високим рівнем сформованості етнічної ідентичності мають статистично вищий рівень показників иілі у житті $\left(\mathrm{M}_{\mathrm{B}}=32,2, \mathrm{M}_{\mathrm{c}}=30,1\right)$ і результат життя $\left(\mathrm{M}_{\mathrm{B}}=32,5, \mathrm{M}_{\mathrm{c}}=30,7\right)$. 


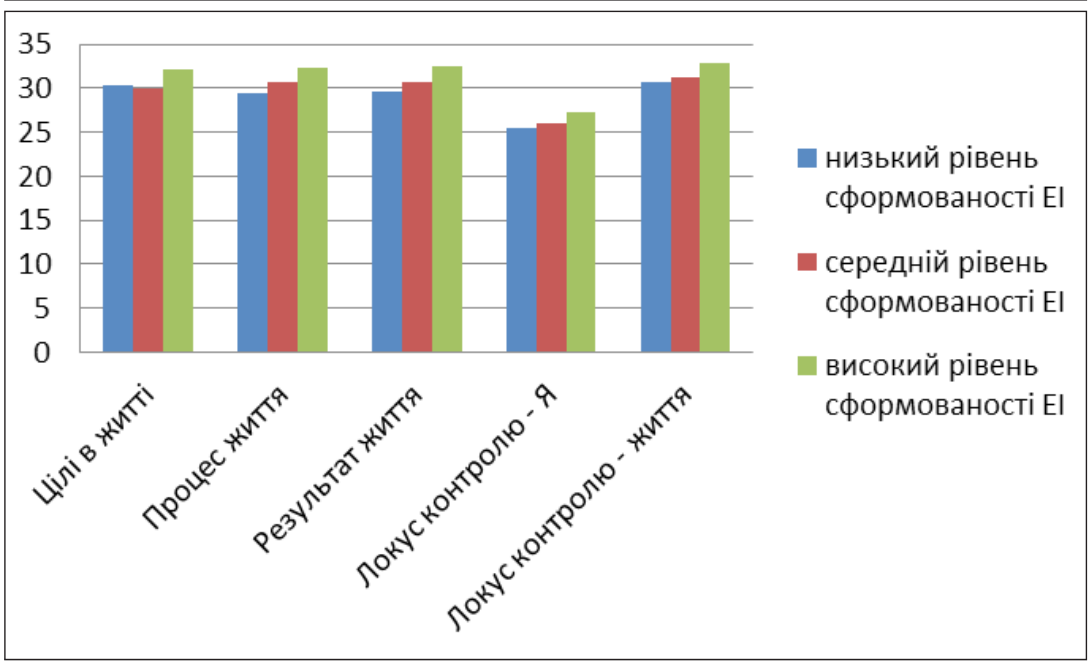

Puc. 3. Порівняння сенсожиттєвих орієнтацій студентів із різним рівнем сформованості етнічної ідентичності

Отож, для студентів із високим рівнем сформованості етнічної ідентичності властиво сприймати сам процес життя як цікавий, емоційно насичений і наповнений змістом, а також оцінювати пройдений відрізок життя як продуктивний і змістовний, загалом, для них властива задоволеність життям. Вони більш схильні вважати себе сильною особистістю, яка володіє правом вибору та здатна самостійно побудувати своє життя згідно зі своїми цілями й уявленнями про його зміст. Окрім того, ця група досліджуваних студентів характеризується більшою переконаністю в тому, що людина може контролювати своє життя, вільно приймати рішення і втілювати їх у життя, а також наявністю в досліджуваних цілей у майбутньому, які надають їхньому життю зміст, напрямок і часову перспективу.

Порівняння виокремлених кластерів за шкалами «Морфологічного тесту життєвих цінностей» В. Сопова i Л. Карпушиної дало змогу виявити значущі відмінності за показниками шкал розвиток себе, духовне задоволення, 
креативність, активні соиіальні контакти, особистий престиж, досягнення, високе латеріальне становище, збереження власної індивідуальності (рис. 4), а також за такими життєвими сферами, як професійна сфера, навчання та освіта, сілейне життя, гроладська діяльність, фізична активність (рис. 5). Статистично значущих відмінностей у студентів із різним рівнем сформованості етнічної ідентичності не виявлено лише за сфрерою захоплень.

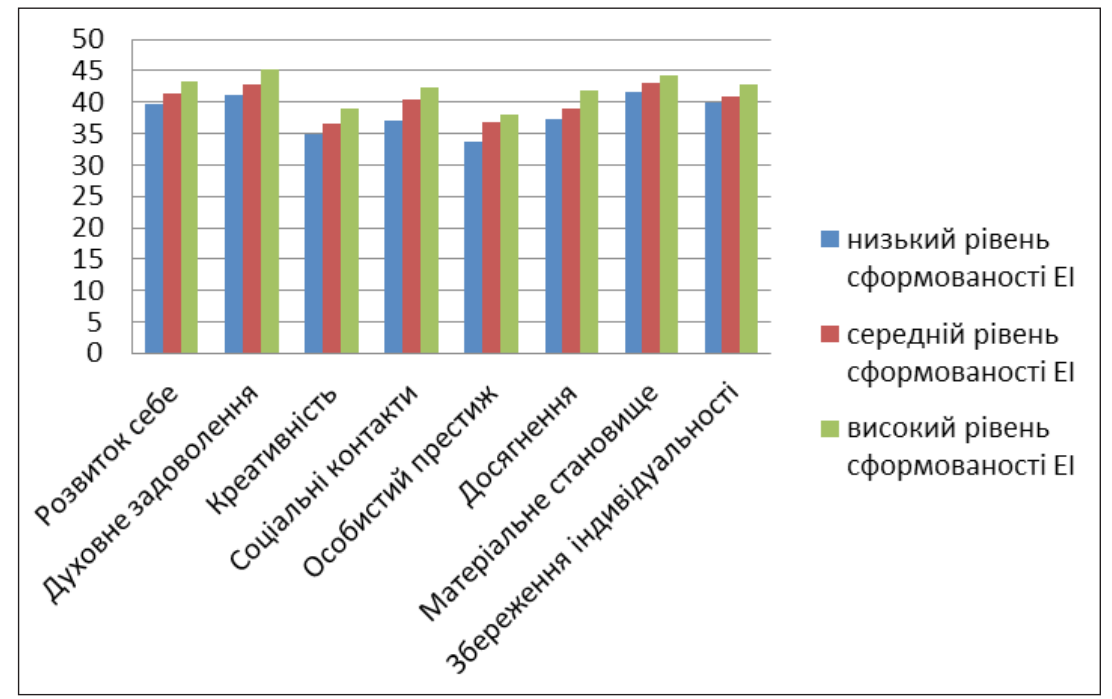

Puc. 4. Порівняння життєвих цінностей студентів із різним рівнем сформованості етнічної ідентичності

Досліджувані студенти з високим рівнем сформованості етнічної ідентичності, порівняно зі студентами із середнім і низьким рівнями сформованості етнічної ідентичності, мають статистично вищий рівень показників розвиток себе $\left(\mathrm{M}_{\mathrm{B}}=43,4, \mathrm{M}_{\mathrm{c}}=41,3, \mathrm{M}_{\mathrm{H}}=39,7\right)$, духовне задоволення $\left(\mathrm{M}_{\mathrm{B}}=45,3, \mathrm{M}_{\mathrm{c}}=42,9, \mathrm{M}_{\mathrm{H}}=41,2\right)$, креативність $\left(\mathrm{M}_{\mathrm{B}}=39,0, \mathrm{M}_{\mathrm{c}}=36,6, \mathrm{M}_{\mathrm{H}}=34,9\right)$, досягнення $\left(\mathrm{M}_{\mathrm{B}}=41,8\right.$, $\left.\mathrm{M}_{\mathrm{c}}=39,1, \mathrm{M}_{\mathrm{H}}=37,4\right)$, збереження власної індивідуальності $\left(\mathrm{M}_{\mathrm{B}}=42,9, \mathrm{M}_{\mathrm{c}}=40,9, \mathrm{M}_{\mathrm{H}}=39,9\right)$. 


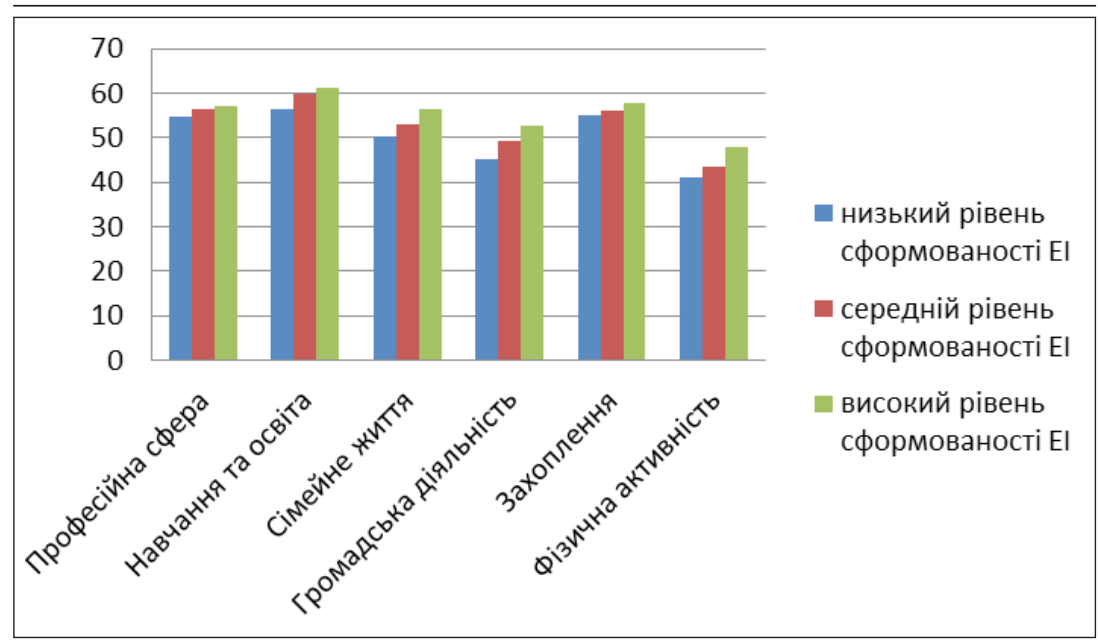

Puc. 5. Значущість життєвих сфер для студентів із різним рівнем сформованості етнічної ідентичності

Отже, студенти з високим рівнем сформованості етнічної ідентичності більш схильні прагнути до самовдосконалення, вважаючи потенційні можливості людини необмеженими, та вірити, що потрібно досягти повної реалізації в житті. Вони більш схильні серйозно ставитись до своїх обов'язків, компетентності та поблажливіше ставитись до інших людей, їхніх недоліків. Цій групі досліджуваних властиве прагнення отримати моральне задоволення в усіх сферах життя та бажання робити винятково те, що цікаво і приносить внутрішнє задоволення. Крім того, вони характеризуються прагненням до реалізації своїх творчих здібностей, внесення змін у всі сфери свого життя, тобто у студентів із високим рівнем сформованості етнічної ідентичності вище бажання уникати стереотипів та урізноманітнювати власне життя. У них спостерігається більше прагнення до досягнення конкретних результатів згідно запланованих подій і цілей, а досягнувши їх, часто мають високу самооцінку. Більш того, студенти з високим рівнем етнічної ідентичності прагнуть зберегти неповторність 
своєї особистості, поглядів, переконань, свого стилю життя, намагаючись якнайменше піддаватись впливу масових тенденцій аж до проявів конфліктності та девіації поведінки.

Виявлено, що студенти з низьким рівнем сформованості етнічної ідентичності, порівняно зі студентами з високим і середнім рівнями сфромованості етнічної ідентичності, мають статистично нижчий рівень показників активні соціальні контакти $\left(\mathrm{M}_{\mathrm{H}}=37,1, \mathrm{M}_{\mathrm{B}}=42,3, \mathrm{M}_{\mathrm{c}}=40,4\right)$ й особистий престиж $\left(\mathrm{M}_{\mathrm{н}}=33,7, \mathrm{M}_{\mathrm{B}}=37,9, \mathrm{M}_{\mathrm{c}}=36,7\right)$. Вони також мають статистично нижчий рівень, порівняно зі студентами з високим рівнем сформованості етнічної ідентичності, життєвої цінності показника високе матеріальне становище $\left(\mathrm{M}_{\mathrm{H}}=41,5, \mathrm{M}_{\text {в }}=44,3\right)$. Вони більш схильні виявляти нерішучість у спілкуванні з незнайомими людьми, небажання бути відкритими i, навіть, недовіру до інших. Ця група досліджуваних характеризується відсутністю бажання бути лідером, бажанням бути поступливими, уникати невдач, конфліктів. Ці студенти більш схильні виявляти байдужість до матеріального добробуту i, навіть, ігнорування матеріального благополуччя як цінності, до якої слід прагнути.

Порівняльний аналіз значущості різних життєвих сфер виявив, що студенти з високим рівнем сформованості етнічної ідентичності, порівняно зі студентами з низьким рівнем сформованості етнічної ідентичності, мають статистично вищий рівень показника професійна сфера $\left(\mathrm{M}_{\text {в }}=57,2, \mathrm{M}_{\mathrm{H}}=54,6\right)$. Вони також, порівняно зі студентами із середнім і низьким рівнями сформованості етнічної ідентичності, мають статистично вищий рівень показника фізична активність $\left(\mathrm{M}_{\mathrm{B}}=47,8, \mathrm{M}_{\mathrm{c}}=43,4, \mathrm{M}_{\mathrm{H}}=41,1\right)$.

Отже, досліджуваним із високим рівнем етнічної ідентичності більш властиво прагнути до максимальної реалізації своїх здібностей у професійній сфері, підвищення своєї кваліфікації, як наслідок - висувати більші вимоги до себе, виконання своїх професійних обов'язків. Важливим 
моментом для них є прагнення мати цікаву, змістовну професію, отримувати від процесу роботи моральне задоволення та мати можливість вносити елементи креативності в сферу своєї професійної діяльності, щось змінювати та модернізувати. Водночас респонденти цієї групи схильні надавати перевагу колегіальній роботі, делегуванню повноважень, установленню доброзичливих стосунків із колегами, тобто позитивному соціально-психологічному клімату в колективі. Володіння професією, що гарантує високий матеріальний дохід, часто виступає для них обов'язковим елементом.

Студенти з низьким рівнем сформованості етнічної ідентичності, порівняно зі студентами з високим і середнім рівнями сформованості етнічної ідентичності, мають статистично нижчий рівень показників навчання та освіта $\left(\mathrm{M}_{\mathrm{H}}=56,3, \mathrm{M}_{\mathrm{B}}=61,2, \mathrm{M}_{\mathrm{c}}=59,7\right)$, сілейне життя $\left(\mathrm{M}_{\mathrm{H}}=50,2\right.$, $\left.\mathrm{M}_{\mathrm{в}}=56,4, \mathrm{M}_{\mathrm{c}}=52,9\right)$ і гроладська ділльність $\left(\mathrm{M}_{\mathrm{H}}=45,0\right.$, $\left.\mathrm{M}_{\text {в }}=52,8, \mathrm{M}_{\mathrm{c}}=49,1\right)$. Варто зазначити, що за життєвими сферами сілейне життя та гроладська діяльність статистично значущі відмінності виявлено між трьома кластерами. Тому можна стверджувати, що студентству з низьким рівнем сформованості етнічної ідентичності притаманно прагнення отримати певний результат, що свідчить про досягнення певного рівня освіти, або ж навіть повне ігнорування освіти як чинника розвитку. Зазвичай, вони характеризуються низькою пізнавальною активністю внаслідок відсутності пізнавального мотиву, прагненням досягти нематеріальних цілей, що пояснюється ідеалістичною спрямованістю особистості, або ж зовнішньою ситуацією, коли, наприклад, їх змусили здобувати освіту. Вони часто демонструють стереотипність мислення, нездатність відійти від зразка.

У сімейних стосунках студенти з низьким рівнем сформованості етнічної ідентичності більш схильні прагнути до збереження консервативних традицій, норм і правил сімейного життя, закріплення своїх позицій у сім’ї. Вони 
можуть виявляти небажання змінювати особистісні якості, які не подобаються чи, навіть, шкодять членам сім’ї. Досліджувані цієї групи характеризуються ігноруванням матеріального достатку як цінності, до якої повинні прагнути усі члени сім’ї, пошуку інших основ для об’єднання сім’ї та бажання побудови взаємозалежної сім’̈̈.

У студентів із низьким рівнем сформованості етнічної ідентичності спостерігається більше прагнення досягти успіхів у громадській діяльності шляхом мінімізації власних зусиль та отримати практичну вигоду від своєї суспільно-політичної діяльності, причому будь-якими способами. Зазвичай, вони демонструють прагнення до деполітизації, ігнорування авторитетів у суспільно-політичному житті. Їм властиве прагнення не виділятись своїми суспільно-політичними поглядами, підтримувати офіційну точку зору. Позиція «бути як усі» - головна позиція у сфері громадської діяльності.

\section{Висновки}

На основі отриманих даних нами 3'ясовано, що ціннісні орієнтації та етнічна ідентичність студентства перебувають у тісному взаємозв'язку. Досліджувані з високим рівнем сформованості етнічної ідентичності більш орієнтовані на сучасні, теперішні події, а не на минуле, схильні цінувати внутрішню свободу, не визнають залежності від найближчого соціального оточення, схильні до прийняття самостійних індивідуальних рішень. Окрім того, вони сприймають процес життя як цікавий, емоційно насичений і наповнений змістом. Їм більш властиво прагнути до максимальної реалізації своїх здібностей у професійній сфері.

Щодо студентства з низьким рівнем етнічної ідентичності, то вони більш схильні виявляти нерішучість у спілкуванні з незнайомими людьми, небажання бути відкритими i, навіть, недовіру до інших. У них відсутне бажання бути лідером, поступливим, уникати невдач і конфліктів. Вони більш схильні виявляти байдужість до матеріально- 
го добробуту, характеризуються низькою пізнавальною активністю, часто демонструють стереотипність мислення. У сімейних стосунках студенти з низьким рівнем сформованості етнічної ідентичності більш схильні прагнути до збереження консервативних традицій, норм і правил сімейного життя. Крім того, студенти з низьким рівнем сформованості етнічної ідентичності більш схильні до досягнення успіхів у громадській діяльності шляхом мінімізації власних зусиль та отримання практичної вигоди від своєї суспільно-політичної діяльності.

\section{Література}

Берберян А. С., Тучина О. Р. Этнос и этничность в современном научном дискурсе. Научные труды КубГТУ. 2014. № 3. С. 155-167.

Галичанська А. В. Родинна традиція як умова запобігання міжпоколінних конфліктів у підлітків в сім'ї: автореф. ... канд. психол. н. Київ, 2011. 19 с.

Глинянюк Н. В. Психолого-педагогічні умови формування ціннісних орієнтацій сучасної студентської молоді [Електронний ресурс]. Режим доступу : http://tme.umo.edu.ua/docs/Dod/3_2010/ Glinaniyk.pdf.

Данилюк I. В. Маргарет Мід як фундатор наукового напряму «Культура і особистість». Психологія і особистість. 2013. № 2. С. 29-42.

Джемс У. Психология. Москва : Педагогика, 1991. 368 с.

Иванова Н. Л. Социальная идентичность в разных социально-культурных условиях. Вопросы психологии. Москва, 2004. № 4. С. 65-75.

Підлужна О. П. Система цінностей як основа формування культури споживання. Наукові записки. Соціологічні науки. 2009. Т. 96. C. $73-77$.

Почебут Л. Г., Мейжис И. А. Социальная психология: учебн. пособ. Санкт-Петербург : «Питер», 2010. 672 с.

Рагозина Т. Э. Культура: исторические судьбы и понятия. Філософія культури: Мова. Раціональність. Освіта. Матеріали Другої Всеукраїнської науково-практичної конференції (20 квітня 2012 р.) / За наук. ред. к. філос. н. П. Г. Давидова. Донецьк : ДонІЗТ, 2012. C. 20-23.

Стефаненко Т. Г. Этнопсихология: учебник. Москва : Аспект-Пресс, 2009. $368 \mathrm{c}$.

Татарко А. Н. Сравнительный анализ структуры ценностей и характеристик этнической идентичности в традиционных и современных культурах. Психологический журнал. 2006. № 4. Т. 27. С. 67-76. 
Эриксон Э. Идентичность: юность и кризис: пер. с англ. / Общ. ред. и предисл. А. В. Толстых. 2-е изд. Москва : Прогресс, 2006. 352 с.

Ядов В. А. Социальные и социально-психологические механизмы формирования идентичности [Электронный ресурс]. Режим доступа : http://ntk.kubstu.ru/file/77.

Diener, E., \& Suh, E. (Eds.) (2000). Culture and subjective well-being. London. P. 185-218.

Marcia, J. E. (2002). Identity and Psychosocial Development in Adulthood. Identity: an International Journal of Theory and Research, 2 (1), $7-28$.

Taylor, D. (2002). The quest for identity. From minority groups to generation. Xers. Praeger.

\section{References}

Berberjan, A. S., \& Tuchina, O. R. (2014). Jetnos i jetnichnost' v sovremennom nauchnom diskurse [Ethnos and ethnicity in modern scientific view]. Nauchnye trudy KubGTU - Research papers of Kuban STU, 3, 155-167 [in Russian].

Galychanska, A. V. (2011). Rodynna tradytsiia yak umova zapobihannia mizhpokolinnykh konfliktiv u pidlitkiv v simi [Family tradition as a condition for preventing generational conflicts in adolescents in the family]. Extended abstract of candidate's thesis. Kyiv [in Ukrainian].

Glynianiuk, N. V. (2010). Psykholoho-pedahohichni umovy formuvannia tsinnisnych oriientatsii suchasnoii studentskoii molodi [Psychological and pedagogical conditions for formation of value orientations of students] Retrieved from http://tme.umo.edu.ua/docs/ Dod/3_2010/Glinaniyk.pdf [in Ukrainian].

Danyliuk, I. V. (2013). Margaret Mid yak fundator naukovoho napriamu «Kultura i osobystist» [Margaret Mid as a founder of scientific direction «Culture and Personality»]. Psykholohiia i osobystist - Psychology and personality, 2, 29-42 [in Ukrainian].

Dzhems, U. (1991). Psychologia [Psychology]. Moskva : Pedagogika [in Russian].

Ivanova, N. L. (2004). Social'naja identichnost' v raznyh social'nokul'turnyh uslovijah [Social identity in different social and cultural conditions]. Voprosy psihologii - Questions on Psychology, 4, 65-75 [in Russian].

Pidluzhna, O. P. (2009). Systema tsinnostei yak osnova formuvannia kultury spozhyvannia [System of values as a basis for formation of consumer culture]. Naukovi zapysky. Sotsiolohichni nauky - Scientific Notes. Sociological Science, 96, 73-77 [in Ukrainian].

Pochebut, L. G. \& Mejzhis, I. A. (2010). Social'naja psihologija [Social psychology ]. Sankt-Peterburg : Piter [in Russian]. 
Ragozina, T. E. (2012). Kul'tura: istoricheskie sud'by i ponjatija [Culture: historical fate and concept]. P. G. Davidov (Eds.). Materialy Druhoi Vseukrainskoi naukovo-praktychnoi konferentsii «Filosofiia kultury: Mova. Ratsionalnist. Osvita»-Proceedings from the second allUkrainian scientific and practical conference. (pp. 20-23). Doneck : DonIZT [in Russian].

Stefanenko, T. G. (2004). Jetnopsihologija [Ethnopsychology]. Moskva : Aspekt-Press [in Russian].

Tatarko, A. N. (2006). Sravnitel'nyj analiz struktury cennostej i harakteristik jetnicheskoj identichnosti v tradicionnyh i sovremennyh kul'turah [Comparative analysis of value structure and ethnic identity characteristics in traditional and modern cultures]. Psihologicheskij zhurnal - Psychological Journal, 27, 4, 67-76 [in Russian].

Jerikson, Je. (2006). Identichnost': junost' $i$ krizis [Identity: adulthood and crisis]. A. V. Tolstyh (Ed. \& Trans.). Moskva : Flinta [in Russian].

Jadov, V. A. (2014). Social'nye i social'no-psihologicheskie mehanizmy formirovanija identichnosti [Social and sociopsychological mechanisms of identity formation]. Retrieved from http://ntk.kubstu.ru/ file/77 [in Russian].

Diener, E., \& Suh, E. (Eds.) (2000). Culture and subjective well-being. London. P. 185-218.

Marcia, J. E. (2002). Identity and Psychosocial Development in Adulthood. Identity: an International Journal of Theory and Research, 2 (1), 7-28.

Taylor, D. (2002). The quest for identity. From minority groups to generation. Xers. Praeger.

\section{Рибак Оксана. Емпіричне дослідження взаємозв'язку ціннісних орієн- тацій та етнічної ідентичності студентської молоді}

\section{АНОТАЦІЯ}

У статті проаналізовано особливості взаємозв'язку ціннісних орієнтацій і сформованості етнічної ідентичності студентської молоді. Для визначення ціннісних орієнтацій студентства використано методики вітчизняних і зарубіжних авторів, зокрема тест культурно-ціннісних орієнтацій Л. Г. Почебут, морфологічний тест життєвих цінностей В. Ф. Сопова і Л. В. Карпушиної, тест сенсожиттєвих орієнтацій Дж. Крамбо і Л. Махолика (адаптація Д. О. Леонтьєва), а для визначення етнічної ідентичності студентської молоді застосовувались шкала експрес-оцінки почуттів, пов'язаних з етнічною приналежністю, Н. М. Лебедєвої, шкала експрес-оцінки вираженості етнічної іден- 
тичності Н. М. Лебедєвої, методика вираженості етнічної ідентичності Дж. Фінні. У дослідженні, що тривало упродовж 2015-2018 років, узяли участь 476 студентів. Проаналізовано виявлені иіннісні орієнтації студентів і рівень їх етнічної ідентичності. Описано статистично значущі відмінності у студентів із різним рівнем сформованості еmнічної ідентичності за такими показниками шкал, як традиційна культура та сучасна культура. Доведено, що студенти більш орієнтовані на теперішнє, на сучасні події. Їхні цінності зосереджені на людині, їі правах, покликанні, розвитку ії здібностей, самореалізації та самоактуалізації. Показано, що студентська молодь схильна визнавати право суспільства регулювати поведінку людини, спираючись на мораль, етичні норми і правила, а також приймати індивідуальні рішення у процесі погодження взаємних потреб, інтересів і планів на майбутнє з групою, сім'єю, робочим колективом. Крім того, частина досліджуваних студентів схильні цікавитись екологічними питаннями, гармонією з природою, ії збереженням. 3’ясовано, що студенти, які надають більшого чи меншого значення різним сорерам життя, мають відмінний рівень етнічної ідентичності. Доведено наявність взаємозв'язку ціннісних орієнтацій і рівня етнічної ідентичності. Зроблено висновок про те, що студенти з певними ціннісними орієнтаціями різняться за рівнем етнічної ідентичності.

Ключові слова: цінності, ціннісні орієнтації, цілі, етнічна ідентичність, рівень етнічної ідентичності, традиційна культура, сучасна культура.

\section{Рыбак Оксана. Эмпирическое исследование взаимосвязи ценностных ориентаций и этнической идентичности студенческой молодежи}

\section{АННОТАЦИЯ}

В cmamье проанализированы особенности взаимосвязи иенностных ориентаций и срормированности этнической идентичности студенческой молодежи. Для определения ценностных ориентаций студенчества был использован комплекс методик отечественных и зарубежных авторов, в частности, тест культурно-ценностных ориентаций Л. Г. Почебут, морфологический тест жизненных иенностей В. Ф. Сопова и Л. В. Карпушиной, тест смысложизненных ориентаций Дж. Крамбо и Л. Махолика (адаптация Д. А. Леонтьева), а также для определения этнической идентичности студенческой молодежи применялись икала экспресс-оценки чувств, связанных с этнической принадлежностью, 
Н. М. Лебедевой, шкала экспресс-оценки выраженности этнической идентичности Н. М. Лебедевой, методика выраженности этнической идентичности Дж. Финни.

В исследовании, которое продолжалось в течение 2015-2018 годов, приняли участие 476 студентов. Проанализированы выявленные ценностные ориентации студентов и уровень их этнической идентичности. Описаны статистически значимые различия у студентов с разным уровнем сорормированности этнической идентичности по таким показателям шкал, как традиционная культура и современная культура. Доказано, что студенты больше ориентированы на настоящее, на современные события. Их ченности сосредоточены на человеке, его правах, призвании, развитии его способностей, самореализации и самоактуализации. Показано, что студенческая молодежь склонна признавать право общества регулировать поведение человека, опираясь на мораль, этические нормы и правила, а также принимать индивидуальные решения в процессе согласования взаимных потребностей, интересов и планов на будущее с группой, семьей, рабочим коллективом. Кроме того, часть испытуемых студентов склонны интересоваться экологическими вопросами, гармонией с природой, ее сохранением. Выяснено, что студенты, которые придают большее или меньшее значение различным сорерам жизни, имеют разный уровень этнической идентичности. Доказано наличие взаимосвязи иенностных ориентаций и уровня этнической идентичности. Сделан вывод о том, что студенты с определенными ценностными ориентациями различаются по уровню этнической идентичности.

Ключевые слова: ценности, ценностные ориентации, цели, этническая идентичность, уровень этнической идентичности, традиционная культура, современная культура. 